\title{
RADIOGRAPHIC ANALYSIS IN CASTOR BEAN SEEDS (Ricinus communis L.) ${ }^{1}$
}

\author{
MARIA LAENE MOREIRA DE CARVALHO²; RENATO AUGUSTO ALVES; \\ LUCIANA MAGDA DE. OLIVEIRA ${ }^{4}$
}

\begin{abstract}
Castor bean cropping has great social and economic value, but its production has been affected by factors such as low quality seeds used for sowing. The quick and precise evaluation of seed quality by x-ray test is known as an effective method to evaluate seed lots, but little is known about the interpretation between of the type of radiographic image and the seed quality correlation. The potential of $\mathrm{x}$-ray analysis as a marker of seed physiological quality and as an initial process for the implementation of the use of computer-assisted image analysis was investigated using castor bean seeds of the different cultivars. The seeds were classified according to internal morphology visualized in the radiography and subjected to the germination test, emergency and seedling growth rate. It was possible to identify the different types of internal tissues, morphological and physical damage in castor bean seeds using the x-ray test. Tissues generating translucent images, embryo deformation, or tissues with less than $50 \%$ of endosperm reserves or spotted, negatively affected the physiological potential of the seed lots. Radiographic analysis is effective as an instrument to improve castor bean seed lot quality. This non destructive analysis allows the prediction of seedling performance and enabled the selection of high-quality seeds under the standards of a sustainable and precision agriculture
\end{abstract}

Index terms: image analysis, $\mathrm{x}$-ray, seed quality.

\section{ANÁLISE RADIOGRÁFICA EM SEMENTES DE MAMONA (Ricinus communis L.)}

\begin{abstract}
RESUMO - A mamona possui alto valor social e econômico, mas sua produção tem sido afetada por fatores como baixa qualidade das sementes utilizadas no plantio. A avaliação rápida e precisa da qualidade de sementes por meio do teste de raios $\mathrm{X}$ é efetiva na análise de lotes de sementes, mas pouco se sabe sobre a interpretação da correlação entre o tipo de imagem radiográfica e a qualidade da semente. O potencial da análise de raios X como um marcador da qualidade fisiológica das sementes é como um processo inicial para a implementação da análise de imagem assistida por computador foi avaliado usando sementes de diferentes cultivares de mamona. As sementes foram classificadas de acordo com a morfologia interna visualizada na radiografia e submetidas aos testes de germinação, emergência e taxa de crescimento de plântula. Foi possível identificar os diferentes tipos de tecidos internos, danos morfológicos e físicos em sementes de mamona por meio do teste de raios $\mathrm{X}$. Tecidos que resultaram em imagens translúcidas, embriões deformados e tecidos com menos de $50 \%$ de endosperma ou manchados afetaram negativamente o potencial fisiológico dos lotes de sementes. A análise radiográfica é eficiente como um instrumento para melhorar a qualidade de lotes de sementes de mamona. Essa análise, não destrutiva, permite prever o desempenho de plântulas e selecionar sementes de alta qualidade sob os padrões de uma agricultura sustentável e de precisão.
\end{abstract}

Termos para indexação: análise de imagens, raios-x, qualidade de sementes.

${ }^{1}$ Submetido em 20/09/2009. Aceito para publicação em 04/12/2009.

${ }^{2}$ Eng. Agr., Dr., Prof. da Universidade Federal de Lavras CP.3037, CEP 37200-000, Lavras MG
${ }^{3}$ Eng. Agr. Universidade Federal de Lavras

${ }^{4}$ Eng. Agr., Dr., Prof Universidade do Estado de Santa Catarina,UDESC Av. Luiz de Camões, 2090 CEP 88520-000 - Lages, SC. 


\section{INTRODUCTION}

Castor bean cropping has become very common, and has been appreciated because of the increase in vegetable oil fuel use and is part of the raw materials of other products. However, its commercialization has found some obstacles, due to the insufficiency of seeds and the deficiency of control in its production.

Castor bean fruit production is directly related to the use of high quality seeds, which can be impaired because of the occurrence of empty, porous, or internally damaged seeds (Santos Neto, 2008).

Among the several tests to evaluate seed quality, the x-ray test, which is fast and non destructive, allows the analyzed seeds to be subjected to physiological tests and, thus, allows the establishment of relationships between internal damage and loss of quality (Carvalho et al, 1999a, 1999b, Dell Aquila,2009). There is also the possibility of automating the evaluation by developing analysis image software (Letang et al, 2002, Dell'Aquila, 2007).

Some authors observed that using x-rays on seeds can also help in their viability analysis, but it still has been necessary to establish relations between the internal structure and the seedling development for each species (Swaminathan; Kamra, 1961; Machado, 2002). The information about seed internal morphology, according to Carvalho (2006) and Oliveira et al (2003), can help in the seed lot selection, decisions about adequate processing of seeds or their rejection, in improvement quality studies and help in germplasm conservation.

Inface of the insufficientinformationaboutcharacterization of castor bean seed internal damage, this study analyzed the potential of radiographic analysis to evaluate seed quality and its use as an instrument to assist in the improvement of seed lot quality, prediction of seedling performance and enabled the selection of high-quality seeds under the standards of a sustainable and precision agriculture.

\section{MATERIAL AND METHODS}

Seeds of the AL Guarany 2002 and IAC- 80 cultivars, from experimental fields in the South of Minas Gerais, Brazil, with moisture contents of $6.5 \%$ and $7.5 \%$, respectively, were used. Pre-tests were done to determine the time and radiation intensity required to obtain radiographic images that showed the castor bean seed internal morphology, and radiation intensity was tested varying from 20 to $50 \mathrm{Kvp}$ and exposure times from 15 to 75 seconds, in Faxitron HP model 43855AX X-ray equipment and Kodak MR 2000 film. After the ideal exposure time and radiation intensity were defined, seeds were arranged on styrofoam sheets $(18 \times 24 \times 1 \mathrm{~cm})$, and radiographed in sufficient number to obtain 400 seeds of each category visualized in the radiographic images, according to internal morphology (Figure 1).
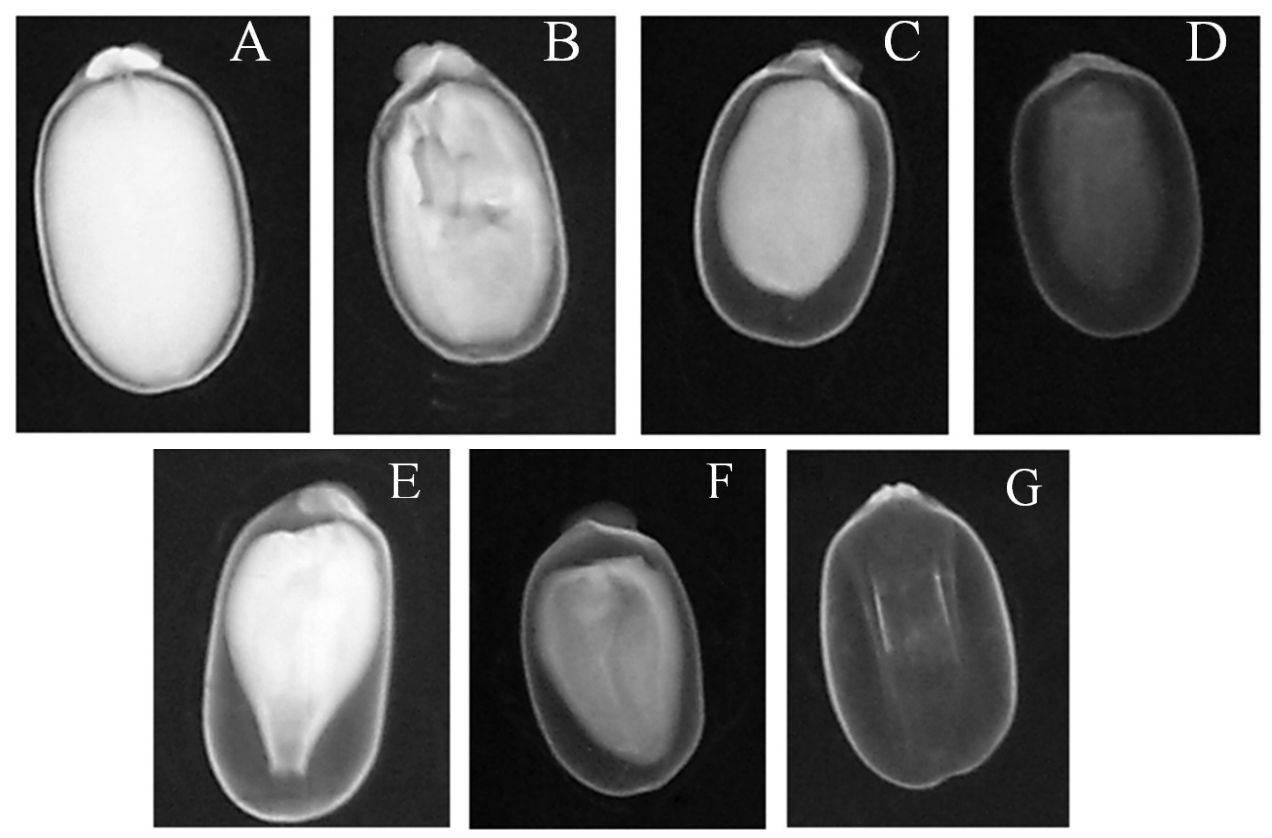

FIGURE 1. Radiographs of castor bean seeds classified into seven categories, according to their internal morphology: A - Full and opaque, B - Full and blemished, C - Partially full and opaque, D - Partially full and translucent, E - Partially full, with embryo deformation, F - Partially full and blemished, G - Empty. 
The seven categories consist of: full seeds, appearing opaque or perfect ( $\mathrm{C}$ - opaque); full seeds, appearing spotted (C-spotted); partially full seed, appearing opaque or perfect (PC-opaque); partially full seeds, with translucent image (PC - translucent); partially full seeds, with embryo deformation (PC - def. embryo); partially full seeds, appearing spotted (PC -spotted) and empty seeds, with less than $50 \%$ of the reserve tissue.

Four replicates of 50 seeds per each seed category were subjected to the following tests: germination (normal seedling and first count), emergence and seedling growth rate (SGR). The germination test was done in rolled up Germitest paper towel, moistened with distilled water (2.5 times the paper weight), and maintained in a germinator at $25^{\circ} \mathrm{C}$. The results were expressed as a percentage of normal seedlings, according to the Rules for Seed Analysis (Brasil, 1992), and the first count was made seven days after sowing. For the emergence test, seeds were sown on a $2: 1$, soil and sand substrate, with periodical watering. The seedling growth rate was determined according to Maguire (1962).

A randomized complete design was used and the means were compared by Scott-Knott test at 5\% probability, using the SISVAR ${ }^{\circledR}$ statistic program.

\section{RESULTS AND DISCUSSION}

Seeds of castor bean of the AL Guarany 2002 and IAC 80 cultivars classified as full and opaque had the greatest germination percentage (Table 1), followed by the seeds with full and spotted images and the partially full and opaque seeds. Seeds classified as partially full and translucent, and those with embryo deformation, presented an intermediate germination index, and those classified as empty had the lowest germination. Comparison of the two cultivars showed that, except for the seeds classified as full - opaque and empty, Al Guarany 2002 was better than IAC 80.

TABLE 1. Castor bean seed germination (\%) of the AL Guarany 2002 and IAC 80 cultivars, *classified as full (C) and partially full (PC).

\begin{tabular}{lcc}
\hline \multirow{2}{*}{ Categories* } & \multicolumn{2}{c}{ CULTIVAR } \\
\cline { 2 - 3 } & AL Guarany 2002 & IAC 80 \\
\hline C - opaque & $94.0 \mathrm{a}$ & $88.5 \mathrm{a}$ \\
C - spotted & $79.0 \mathrm{~b}$ & $51.5 \mathrm{~b}$ \\
PC - opaque & $85.5 \mathrm{~b}$ & $50.5 \mathrm{~b}$ \\
PC - translucent & $46.0 \mathrm{~d}$ & $18.5 \mathrm{c}$ \\
PC - embryo def. & $42.5 \mathrm{~d}$ & $13.0 \mathrm{c}$ \\
PC - spotted & $56.5 \mathrm{c}$ & $41.5 \mathrm{~b}$ \\
Empty & $1.0 \mathrm{e}$ & $0.5 \mathrm{~d}$ \\
\hline
\end{tabular}

In the vertical column two means with a letter in common are not significantly $(\mathrm{p}<0.05)$ different by the Scott-Knott test at $5 \%$ probability.

The results of the germination test (Table 2) showed that for the Al Guarany 2002 cultivar, seeds in the partially full with embryo deformation and partially full and spotted categories presented a higher percentage of deformed abnormal seedlings. In general, seeds of the IAC 80 cultivar presented more deformed abnormal seedlings than the Al Guarany 2002 cultivar.

There were differences in seed vigor according to the different damage category classification (Table 3 ). Partially full, translucent and empty seeds were less vigorous, demonstrating the test efficacy in identifying low quality seeds and the importance of seed reserve tissue for its vigor. Seeds of the AL Guarany 2002 cultivar that gave opaque images and were classified as full had greater performance than all the others; similar results were found for the IAC 80 cultivar.

The seed moisture contents varied from $6.5 \%$ for $\mathrm{AL}$ Guarany 2002 to $7.5 \%$ for IAC 80 , showing the uniformity of the seeds lots in relation to the moisture contents, since the seed internal structures were perfectly visualized due to the low water contents. According to Simak (1991), seed moisture affects optical density, meaning that the lower the seed moisture, the greater its optical density, allowing better differentiation of seed structures viewed in radiographs.

For both cultivars, seeds with internal damage detected by the x-ray image were negatively affected in their germination. 
TABLE 2. Percentage of castor bean deformed abnormal seedlings, infected abnormal, and dead seedlings of the cultivares AL Guarany 2002 and IAC 80 cultivars, *classified in the categories full (C) and partially full (PC) subjected to the germination test.

\begin{tabular}{|c|c|c|c|c|c|c|}
\hline \multirow{2}{*}{ Categories* } & \multicolumn{2}{|c|}{$\begin{array}{c}\text { Deformed abnormal } \\
\text { seedlings }\end{array}$} & \multicolumn{2}{|c|}{ Infected abnormal seedlings } & \multicolumn{2}{|c|}{ Dead seedlings } \\
\hline & $\begin{array}{l}\text { AL Guarany } \\
2002\end{array}$ & IAC 80 & $\begin{array}{l}\text { AL Guarany } \\
2002\end{array}$ & IAC 80 & $\begin{array}{l}\text { AL Guarany } \\
2002\end{array}$ & IAC 80 \\
\hline $\mathrm{C}$ - opaque & $2.0 \mathrm{~b}$ & $6.0 \mathrm{~b}$ & $0.5 \mathrm{a}$ & $4.0 \mathrm{~b}$ & $3.5 \mathrm{e}$ & $1.5 \mathrm{~d}$ \\
\hline $\mathrm{C}$ - blemished & $5.5 \mathrm{~b}$ & $26.5 \mathrm{a}$ & $3.0 \mathrm{a}$ & $17.0 \mathrm{a}$ & $12.5 \mathrm{e}$ & $5.0 \mathrm{~d}$ \\
\hline PC - opaque & $2.5 \mathrm{~b}$ & $23.0 \mathrm{a}$ & $4.5 \mathrm{a}$ & $24.0 \mathrm{a}$ & $7.5 \mathrm{e}$ & $2.5 \mathrm{~d}$ \\
\hline PC - translucent & $3.0 \mathrm{~b}$ & $21.0 \mathrm{a}$ & $3.0 \mathrm{a}$ & $15.5 \mathrm{a}$ & $48.0 \mathrm{~b}$ & $45.0 \mathrm{~b}$ \\
\hline PC - def. embryo & $13.0 \mathrm{a}$ & $32.5 \mathrm{a}$ & $7.0 \mathrm{a}$ & $14.0 \mathrm{a}$ & $37.5 \mathrm{c}$ & $40.5 \mathrm{~b}$ \\
\hline PC - blemished & $10.5 \mathrm{a}$ & $26.5 \mathrm{a}$ & $10.0 \mathrm{a}$ & $13.5 \mathrm{a}$ & $23.0 \mathrm{~d}$ & $18.5 \mathrm{c}$ \\
\hline Empty & $2.0 \mathrm{~b}$ & $5.0 \mathrm{~b}$ & $1.0 \mathrm{a}$ & $0.0 \mathrm{~b}$ & $96.0 \mathrm{a}$ & $94.5 \mathrm{a}$ \\
\hline
\end{tabular}

Means followed by the same lowercase letter in the column, are not significantly different by the Scott-Knott test at 5\% probability.

TABLE 3. First germination count (FC\%), emergence (E\%) and seedling growth rate (SGR) of castor bean seeds of the AL Guarany 2002 and IAC 80 cultivars, *classified as full (C) and partially full (PC).

\begin{tabular}{lcccccc}
\hline \multirow{2}{*}{ Categories* } & \multicolumn{5}{c}{ CULTIVAR } \\
\cline { 2 - 7 } & \multicolumn{3}{c}{ AL Guarany 2002 } & \multicolumn{3}{c}{ IAC 80 } \\
\cline { 2 - 7 } & $94.0 \mathrm{a}$ & $98.5 \mathrm{a}$ & $4.82 \mathrm{a}$ & $73.5 \mathrm{a}$ & $82.5 \mathrm{a}$ & $3.18 \mathrm{a}$ \\
\hline C - opaque & $68.5 \mathrm{~b}$ & $88.5 \mathrm{~b}$ & $3.93 \mathrm{~b}$ & $19.0 \mathrm{~b}$ & $74.0 \mathrm{~b}$ & $2.61 \mathrm{~b}$ \\
$\mathrm{C}-$ blemished & $68.0 \mathrm{~b}$ & $89.0 \mathrm{~b}$ & $3.92 \mathrm{~b}$ & $8.5 \mathrm{c}$ & $55.5 \mathrm{c}$ & $1.66 \mathrm{c}$ \\
PC - opaque & $26.0 \mathrm{~d}$ & $48.5 \mathrm{~d}$ & $1.87 \mathrm{~d}$ & $3.5 \mathrm{c}$ & $24.0 \mathrm{e}$ & $0.71 \mathrm{e}$ \\
PC - translucent & $25.0 \mathrm{~d}$ & $66.0 \mathrm{c}$ & $2.59 \mathrm{c}$ & $1.5 \mathrm{c}$ & $35.5 \mathrm{~d}$ & $1.04 \mathrm{~d}$ \\
PC - def. embryo & $44.5 \mathrm{c}$ & $71.0 \mathrm{c}$ & $2.85 \mathrm{c}$ & $5.5 \mathrm{c}$ & $56.5 \mathrm{c}$ & $1.74 \mathrm{c}$ \\
PC - blemished & $0.0 \mathrm{e}$ & $0.0 \mathrm{e}$ & $0.00 \mathrm{e}$ & $0.0 \mathrm{c}$ & $1.0 \mathrm{f}$ & $0.03 \mathrm{f}$ \\
Empty & & &
\end{tabular}

Means followed by the same lowercase letter in the column are not significantly different by the Scott-Knott test at $5 \%$ probability.

These results showed the efficiency of evaluating the internal morphology of castor bean seeds by image analysis. Similar results have been reported for others species by Oliveira et al. (2003) who used the x-ray test to evaluate the quality of Peltophorum dubium seeds; and Leon et al. (1986), who concluded that only the x-ray methodology was able to detect internal mechanical damage in seeds and Cícero et al. (1998), who used image analysis to identify the effects of mechanical damage on maize seed germination.

There were some differences in cultivar reaction to the type of damage detected in the radiograph image and the percentage of deformed abnormal, infected, and dead seedlings. However, the negative effect of empty seeds and the damage in the partially full seed with embryo deformation or translucent was evident.

Significant differences were observed among the categories from the results of emergence and EVI. Empty seeds had the lowest index, for both cultivars, followed by those partially full and translucent, and those with embryo deformation; in contrast, the full and opaque seeds emerged earlier, indicating better vigor. Comparing both cultivars, for all categories, AL Guarani was greater than IAC 80, except for the empty seeds, in which they were similar. These differences between the cultivars could be explained by the 
deterioration level, in view of the fact that seeds from the IAC 80 cultivar were more deteriorated than seeds from the AL Guarani cultivar, and by the water absorption ability that could be different between different genetic materials (Souza, 2007).

The opaque seeds of both cultivars presented superior vigor than those with internal damage, in all categories, in relation to the standard establishment and germination velocity. These numbers showed that seed reserves are fundamental for seedling development, especially under adverse sowing conditions, as in vigor tests.

The radiographic analysis allowed the conclusion that partially full seeds, visualized by the x-ray test, presented inferior germination, emergence and vigor and were also more affected by damage. Of all types of images observed, the empty seeds most affected seed quality, followed by partially full seeds with embryo deformation and those with translucent appearance.

\section{CONCLUSION}

The analysis of images obtained by x-rays was helpful to evaluate castor bean seed quality and an instrument to facilitate seed lot quality improvement. It was possible to identify, through the radiography images, the different types of internal tissue and morphological and physical damage that can occur in castor bean seeds that affect the physiological quality of the seed lots. Tissues generating translucent, spotted, with embryo deformation images, or tissues with less than $50 \%$ of the endosperm, have a negative influence on the quality of castor bean seed lots.

\section{ACKNOWLEDGEMENTS}

To CNPq - Conselho Nacional Científico e Tecnológico and FAPEMIG - Fundação de Amparo à Pesquisa do Estado de Minas Gerais for the financial support.

\section{REFERENCES}

BRASIL. Ministério da Agricultura e Reforma Agrária. Secretaria Nacional de Defesa Agropecuária. Departamento Nacional de Produção Vegetal. Coordenação de Laboratório Vegetal. Regras para análise de Sementes. Brasília, DF, 1992. 365p.

CARVALHO, M.L.M.; HOEKSTRA, F.A.; AELST, A.C.V.; ECK, J.W.V. Caracterização de danos de estresse em précolheita e seus efeitos na qualidade fisiológica de sementes de milho. [Characterization of pre-harvest stress damage and its effects on physiological quality of maize seed]. Revista Brasileira de Sementes, v.21, n.1, p.93-100, 1999a.

CARVALHO, M.L.M.; VAN AELST, A.C.; VAN ECK, J.W.; HOEKSTRA, F.A. Pre-harvest stress cracks in maize (Zea mays L.) kernels as characterized by visual, $\mathrm{X}$-ray and low temperature scanning electron microscopical analysis: effect on kernel quality. Seed Science Research, v.9, n.3, p.227-236, 1999b.

CARVALHO, M.L. de. Raio-x na avaliação da qualidade de Sementes. Informativo ABRATES, v.16, n.1/2, p.93-99, 2006.

CICERO, S.M. et al. Evaluation of mechanical damage in seeds of maize (Zea mays L.) by X-ray and digital imaging. Seed Science and Technology, v.26, p.603-612, 1998.

DELL' AQUILA, A. Development of novel techniques in conditioning, testing and sorting seed physiological quality. Seed Science and Technology, v.37, n 3, p. 608-624, 2009.

ISTA. International Rules for Seed Testing. Seed Science and Technology, v.24, 1996. 336p. Supplement.

LEON, G.G. et al. Utilização de filmes radiográfico, pancromático e infravermelho na avaliação de danos em sementes. [Use of radiographic films, infrared and panchromatic the assessment of damages in seed] Revista do Centro de Ciências Rurais, v.16, p.303-318, 1986.

LETANG, J.M.; PEIX, G.; DROULEZ, J. Automatic selection of seeds using pattern recognition techniques in high resolutin x-ray images. NDT.net - December 2002, vol. 7 n. 12

MACHADO, C.F. Metodologia para Condução do Teste de Germinação e Utilização de Raios X para a Avaliação da Qualidade de Sementes de Aroeira-branca (Lithraea molleoides (Vell.) Engl.) [Methodology for Driving the Germination Test and Use of X-ray to Evaluate Quality of Seed of Lithraea molleoides (Vell.) Engl], Piracicaba SP, 2002.

MAGUIRE, J.D. Speed of germination-aid in selection and evaluation for seedling emergence and vigor. Crop Science, v.2, n.1, p.176-177, 1962.

OLIVEIRA, L.M.; CARVALHO, M.L.M.; DAVIDE, C.A. Utilização do teste de raios-x na avaliação da qualidade de sementes de canafístula (Peltophorum dubium (Sprengel) Taubert. [Using $x$-ray test in evaluating the quality of canafístula seed (Peltophorum dubium (Sprengel) Taubert]. Revista Brasileira de Sementes, v.25, n.1, p.116-120, 2003. 
SANTOS NETO, A.L Qualidade de sementes de mamona beneficiadas e tratadas com fungicidas [Quality of processed and fungicide-treated castor bean seeds]. 2008 108p. tese (doutorado em fitotecnia) Universidade Federal de Lavras, Lavras.

SEVERINO, L.S.; COELHO, D.K., CARDOSO, G. D. Caracterização de sementes de mamona em diferentes faixas de peso. [Characterization of castor bean seeds in different weight ranges] I Congresso Brasileiro de Mamona 1, 2004. Campina Grande. Anais... Campina Grande: Embrapa Algodão, 2004, 1 cd rom.
SIMAK, M. Testing of forest tree and shrub seeds by X-radiography. In: GORDON, A. G.; GOSLING, P.; WANG, B. S. P. (Ed.) Tree and shrub seed handbook. Zurich: ISTA, 1991.

SOUZA, L.A. Electrical conductivity test to evaluate quality of castor seeds. 2007- 53p. Dissertation (Masters Degree program in Agronomy) - Federal University of Lavras, Lavras, Minas Gerais, Brazil.

SWAMINATHAN, M.S.; KAMRA, S.K. X-ray analysis of the anatomy and viability of seeds of some economic plants. Indiam Journal of Genetics \& Plant Breeding, v.21, n.2, p.129-135, 1961. 